\title{
Pesquisa
}

\section{O COMPORTAMENTO DO PRIMEIRO EMPREGO NA INDÚSTRIA DE TRANSFORMAÇÃO DO ESTADO DO CEARÁ}

\author{
Diana Figueiredo Barbosa (1) \\ Sandra Maria Santos (2) \\ Francisco de Assis Soares (3) \\ Ana Marilia Barbosa Sampaio (4)
}

\begin{abstract}
Resumo
O processo de inserção da economia brasileira no contexto internacional, nos anos noventa, repercutiu no ambiente competitivo das empresas, pois para enfrentar a concorrência dos produtos importados, a indústria brasileira procurou modernizar-se, seja, pela adoção de novas tecnologias e técnicas de gestão de trabalho ou pelo aperfeiçoamento da qualidade dos produtos. Esse cenário de mudanças e transformações da economia brasileira se refletiu no mercado de trabalho, em especial, daqueles que estão em busca do primeiro emprego. Todas essas mudanças tiveram efeitos sobre o emprego industrial, pois representaram ajustes produtivos com o propósito de reduzir custos e obter ganhos de eficiência, os quais se expressam em aumento de produtividade. Nesse sentido, os trabalhadores que buscam o primeiro emprego encontram maiores dificuldades para se inserir no mercado de trabalho, principalmente, devido à falta de experiência e qualificação. O governo do Estado do Ceará, em relação aos anos 90, intensificou suas ações no sentido de dinamizar indústria cearense, com base em concessões financeiras e apoio de infraestrutura às empresas que desejassem ampliar, modernizar ou investir em novas instalações. Isto repercutiu favoravelmente na economia cearense, atraindo empresas de outros estados. Com isso, tem-se observado um dinamismo na indústria de transformação do Estado, e que tem reflexos no mercado de trabalho. Dessa forma, surgiu o interesse em analisar o comportamento do primeiro emprego na indústria de transformação do Estado do Ceará no período de 1994-2009. Trata-se de uma pesquisa de natureza descritiva. O estudo compreende a análise do período entre 1994 e 2009,


tendo como fontes principais de dados o Instituto Brasileiro de Geografia e Estatística (IBGE), Instituto de Pesquisas Estratégias do Estado do Ceará (IPECE) e os dados do Relatório Anual de Informações Sociais (RAIS). A pesquisa apontou mudanças relevantes no comportamento do primeiro emprego não somente na perspectiva espacial como também setorial. No âmbito das mesorregiões, favorecidas pela política de interiorização do Estado, destacaram-se em termos do crescimento observado no período em relação ao primeiro emprego as mesorregiões: Centro Sul Cearense e Noroeste. No que se refere à estrutura produtiva, evidencia-se que as atividades mais tradicionais continuam liderando a absorção do primeiro emprego, pela própria natureza delas intensivas em mão de obra. Observou-se que em 1990, as atividades de fabricação de produtos alimentares e bebidas, confecção de artigos do vestuário e acessórios e fabricação de produtos têxteis responderam por quase $70 \%$ do primeiro emprego da indústria de transformação. No ano de 2009, a atividade de preparação de couros e fabricação de artefatos de couro, artigos de viagem respondeu por 36,87(\%), tendo um dos mais expressivos crescimentos no primeiro emprego do período $(1151,29 \%)$.

Palavras-chave: Primeiro Emprego. Mercado de Trabalho. Indústria de Transformação do Ceará.

\section{Introdução}

A partir da década de 1990, o mercado de trabalho brasileiro passou por grandes transformações especialmente nos últimos anos, devido a mudanças estruturais acarretadas por alterações importantes no cenário econômico, como a estabilização macroeconômica e o processo de abertura comercial. De acordo com Posthuma (1999) esta década também foi marcado pela adoção de políticas monetaristas de controle inflacionário baseados em altas taxas de juros, que por sua vez têm enfraquecido a capacidade de crescimento das empresas nacionais.

No que se refere à política monetária, enfatizou-se uma política restritiva com taxas de juros reais elevadas, objetivando o controle da demanda agregada e a atração de capitais estrangeiros. A política cambial objetivou a manutenção da estabilidade e caracterizou-se por 
taxas de câmbio valorizadas estimulando o aumento da competitividade, e por fim, a política fiscal foi marcada por maior austeridade, com amplo processo de privatização das estatais.

No Brasil, principalmente a partir dos anos 1990, quando as políticas macroeconômicas foram implementadas, aumentou a problemática do emprego devido às oscilações na produção e consumo que o sistema econômico sofreu. Como aponta Dedecca (2005) aqueles que aspiravam ao primeiro emprego na década de 1990 se depararam com maiores dificuldades de inserção no mercado de trabalho, sendo decorrência das maiores exigências de qualificação e experiência.

A nível de Ceará, na década de noventa o estado conduziu uma política industrial baseada na concessão de incentivos fiscais, para atração de investimentos e fomento à industrialização. Isto teve reflexos na performance econômica, uma vez que com o Produto Interno Bruto cresceu nesse período a taxas maiores que o nacional, destacando-se o aumento da participação do setor industrial, em especial na indústria de transformação e construção civil (IPECE, 2009). Ressalta-se que no ano de 2009 o Estado apresentou a segunda maior geração de emprego do Nordeste sendo superado pelo Estado de Pernambuco e Bahia (BNB, 2010).

A partir da contextualização feita, e mais especificamente sobre o primeiro emprego, esse estudo tem como questão de pesquisa: Qual o comportamento do primeiro emprego considerando as políticas de apoio ao setor industrial no Estado do Ceará?, que tem como objetivos analisar esse comportamento na indústria de transformação do Estado no período de 1994-2009, investigar a evolução da estrutura do primeiro emprego industrial nas mesorregiões e identificar o perfil do trabalhador do primeiro emprego na indústria de transformação analisando a contribuição da estrutura industrial cearense para a geração do primeiro emprego.

O trabalho trata-se de uma pesquisa de natureza descritiva com abordagem quantitativa, utilizando-se fontes secundárias, sendo inclusos nestas fontes artigos, dissertações e publicações de entidades relacionadas ao foco de estudo. Os dados referem-se ao período de 1994 a 2009 e, no contexto espacial, o campo de abrangência do estudo são as mesorregiões geográficas do Estado do Ceará.

O trabalho está composto em sete seções, a primeira corresponde, conforme já apresentada a introdução. A seguir tem-se a seção 2 que apresenta uma contextualização do mercado de trabalho no âmbito teórico, bem como das políticas públicas relativas ao primeiro emprego no Brasil. Na seção 3, aborda-se a política de promoção à industrialização no Estado do Ceará. As considerações metodológicas apresentam-se na seção 4. Segue-se a seção 5 de 
análise dos resultados, seguindo-se as considerações finais na seção 6 e, por último, as referências.

\section{Mercado de Trabalho e Respostas Governamentais}

De acordo com Ehrenberg e Smith (2005) o mercado de trabalho é composto de todos os compradores e vendedores de trabalho. Para tal, no lado da oferta de mão-de-obra estão os trabalhadores os quais oferecem unidade de trabalho no mercado de trabalho em proporção com o salário real que é oferecido pela empresa, e cujas decisões sobre onde trabalhar devem levar em conta outras opções tais como condições ambientais de trabalho, horas trabalhadas e possibilidades de ascensões profissionais. Em contraposição, existe o chamado mercado informal de trabalho, onde prevalecem regras de funcionamento com um mínimo de interferência do Estado e, ainda que a dimensão do mercado informal possa ser relativamente grande, a dinâmica da economia é fornecida pelo setor formal.

Utilizando dados oficiais do IBGE, Najberg e Ikeda (1999), determinaram três tipos de empregos na economia brasileira: o emprego direto corresponde à mão-de-obra adicional requerida por um setor, podendo observar o aumento de produção; o emprego indireto corresponde aos postos de trabalho que surgem nos setores que compõem a cadeia produtiva, já que a produção de um bem final estimula a produção de todos os insumos necessários à sua produção; por fim, o emprego efeito-renda que é obtido a partir da transformação da renda dos trabalhadores e empresários em consumo. Parte da receita das empresas auferida em decorrência da venda de seus produtos se transforma em renda dos trabalhadores e dos empresários.

Nesse contexto, ressalta-se o papel das políticas macroeconômicas, onde a defesa do pleno emprego, a partir das forças produtivas capitalistas consolida-se como um resultado histórico. São os fundos de financiamento público ou privado que estabelecem acesso às garantias mínimas de proteção social, através das políticas de bem-estar que visam definir o grau possível de incorporação da classe trabalhadora aos frutos do desenvolvimento econômico. E, tem-se também as políticas específicas voltadas para o mercado de trabalho, onde o papel consiste em orientar tanto a redução dos desajustes nas ocupações e rendimentos que ocorrem no plano nacional, regional e setorial, quanto os problemas de qualificação profissional, de alocação de mão-de-obra, das condições e relações de trabalho, dentre outros (NAJBERG; PEREIRA, 2004). 
No que se refere às políticas voltadas para o mercado de trabalho, Calmfors (1994) classificam-nas em dois grandes grupos, sendo o primeiro que envolve a questão do grau de flexibilidade do mercado de trabalho, notadamente no que se refere ao custo da mão-de-obra, a partir de um ponto de vista que identifica na rigidez deste mercado algum elemento que dificulta a possibilidade de geração de emprego. O segundo compreende as chamadas políticas ativas de mercado de trabalho, as quais englobam um elenco de medidas destinadas a aperfeiçoar o funcionamento do mercado de trabalho para beneficiar os desempregados.

Seguindo uma classificação proposta por Calmfors (1994), é possível identificar três subcategorias básicas: a) a intermediação de emprego, que visa aproximar a oferta e demanda por trabalho e tornar mais eficiente o processo de matching entre postulantes e vagas disponíveis; b) o treinamento no mercado de trabalho destinado a qualificar a mão de obra para ajustá-la às novas demandas por trabalho; e c) a criação direta de empregos, via setor público ou subsídios ao setor privado. Desta forma, as duas primeiras subcategorias lidam, respectivamente, com o desemprego friccional e com o desemprego tecnológico.

De acordo com Ramos (2003), as políticas de emprego se dividem entre as políticas passivas e ativas. As políticas de emprego denominadas de passivas são as ações que tendem a tornar mais "tolerável" a condição de desempregado mediante uma transferência monetária a todo trabalhador desempregado, tendo como principais mecanismos: seguro desemprego, extensão dos ciclos escolares e aposentadoria precoce, dentre outros. Pode parecer paradoxal que o seguro-desemprego seja denominado de "Política de Emprego", pois sendo um benefício financeiro outorgado a um indivíduo devido a sua condição de desempregado, se o mesmo consegue emprego deixaria de ter direito a esse benefício.

Prosseguindo com Ramos (2003) a formação profissional talvez seja a Política Ativa mais popular, tanto no Brasil como nos países mais desenvolvidos. É uma Política Ativa dado que se parte da suposição que ao elevar a qualificação ou formação de um indivíduo aumentam suas chances de encontrar emprego.

\section{Políticas Públicas de Emprego no Brasil}

As Políticas Públicas de Emprego estão inclusas no Sistema Público de Emprego e têm respaldo na Constituição Federal. O fundamento principal dessas Políticas está no art. 239 da Constituição Federal que reza "A arrecadação decorrente das contribuições para o Programa de Integração Social, criado pela Lei Complementar $n^{\circ} 7$, de 7 de setembro de 
1970, e Lei Complementar ${ }^{\circ}$ 8, de 3 de dezembro de 1970, para financiar, nos termos que a lei dispuser, o programa do seguro-desemprego." através dos recursos do PIS/PASEP, que constituem o Fundo de Amparo do Trabalhador (FAT).

De acordo com a Lei 8900/94 todas as ações de Políticas Públicas de Emprego devem ser integradas, notadamente no Sistema Público de Emprego (intermediação de mão-de-obra, por meio do SINE, Qualificação Social e Profissional - PNQ, Concessão do Seguro Desemprego e Política de Inserção da Juventude - PNPE) auxiliando "os trabalhadores na busca de emprego, promovendo, para tanto, ações integradas de orientação, recolocação e qualificação profissional" (BRASIL, 1994).

Por sua vez, de acordo com a Lei 7998/90 todas essas ações devem ser deliberadas dentro da gestão participativa tripartite dos Trabalhadores, Empresários e Governo. Os empresários, Estado e trabalhadores, devem estar empenhados em reduzir os efeitos do desemprego, auxiliar na tarefa de orientação, recolocação e qualificação profissional.

Dentro dos projetos prioritários do governo federal no plano plurianual "Brasil em Ação" está o Plano Nacional de Educação Profissional (PLANFOR), iniciado em 1995, o plano é um dos mecanismos de política pública de trabalho e renda vinculado ao Fundo de Amparo ao Trabalhador (FAT) do Ministério do Trabalho e Emprego (MTE). Os recursos para a execução são oriundos do Conselho Deliberativo do Fundo de Amparo ao Trabalhador (CODEFAT) e são repassados aos estados ou a parceiros nacionais ou regionais por meio de convênios. Todos os convênios exigem uma contrapartida, definida em lei para os estados.

Outrossim, o Programa Nacional de Estímulo ao Primeiro Emprego (PNPE) foi criado pela Lei $\mathrm{N}^{\circ} 10.748 / 03$, objetivando promover a qualificação do jovem para o mercado e inclusão social, bem como a criação de postos de trabalho para jovens ou prepará-los para o mercado de alternativas, geradoras de renda. Essa lei foi alterada pela Lei $N^{\circ} 10.940 / 2004$ e regulamentada pelo Decreto 5.199/2004.

O Programa Primeiro Emprego consistiu no pagamento de auxílio financeiro, uma subvenção anual no montante de $\mathrm{R}$ \$ 1,5 mil para pequenas empresas e $\mathrm{R}$ \$ 2,4 mil para grandes empresas, que contratassem jovens sem experiência anterior. O Programa teve duração até 2007 e seu alcance, ao longo de quatro anos (2003-2007), foi de 350,4 mil jovens, os quais conseguiram emprego diretamente por meio de ações do primeiro emprego, enquanto a meta era 450 mil apenas para o primeiro ano (BRASIL, 2009).

Tokarski (2007) aponta que a explicação para esses resultados pode estar ligada a vários fatores entre os quais o compromisso da empresa de manter o jovem contratado por determinado período, num mercado caracterizado pela alta rotatividade como é o caso do 
brasileiro, além disso, a empresa deveria efetuar o pagamento de impostos e tributos federais com regularidade entre outros fatores.

Em 2007 a ação de subvenção foi cancelada e a orientação voltou-se para a busca em garantir a qualidade da oferta de cursos de qualificação, o que foi feito pelo fortalecimento do programa Projovem com vistas a garantir maior abrangência, integração e visibilidade das ações de juventude do Governo Federal. O Programa tem a gestão compartilhada pelos Ministérios da Educação, Trabalho e Emprego e do Desenvolvimento Social e Combate a Fome, sob a coordenação da Secretaria Nacional de Juventude, vinculada a Secretaria Geral da Presidência da República (BRASIL, 2009).

\section{Políticas para Juventude no Ceará}

O Programa Gestão de Políticas de Juventude está sendo executado de forma articulada com as demais ações voltadas para a juventude do estado. Este segmento vem sendo considerada uma das prioridades da Secretaria do Trabalho e Desenvolvimento Social, na busca de contribuir para a inserção dos jovens cearenses no mercado de trabalho, por meio da qualificação social e profissional, fortalecendo as oportunidades para o primeiro emprego, em especial com a ampliação dos projetos Primeiro Passo e Jovem Aprendiz em serviço.

O Programa Primeiro Passo tem como objetivo incluir socialmente e ampliar o acesso dos jovens ao emprego. O projeto atua na preparação da classe juvenil, através de cursos profissionalizantes nas áreas de serviços, turismo e administração. Destaca-se que o Primeiro Passo é importante porque atua na transformação da vida dos jovens entre 16 e 24 anos, visando o resgate da cidadania dos jovens assistidos, pois é destinado aos jovens em situação de risco e vulnerabilidade social. O projeto já está presente em 134 municípios cearenses e, no ano de 2010, superou a meta proposta de beneficiar cinco mil jovens. Os jovens são qualificados em três linhas de ação: Jovem Bolsista, Jovem Aprendiz e Jovem Estagiário. (CEARÁ, 2010)

O Jovem Aprendiz é capacitado em cursos e, no turno oposto ao da capacitação é encaminhado para uma empresa, que pode ser pública ou privada. $\mathrm{Na}$ empresa os respectivos jovens têm a oportunidade de entrar em contato com o mercado de trabalho e ainda recebem auxílio fornecido pela própria empresa. 
No caso do Jovem Estagiário, o projeto faz uma seleção dos jovens de acordo com o perfil solicitado pela empresa, permanecendo um ano no estágio e são inseridos no mercado de trabalho formal.

\section{Conjuntura Econômica Brasileira e a Performance do Mercado de Trabalho}

Conforme Deddeca (2005) a política macroeconômica dos anos noventa mudou o ambiente competitivo das empresas. Na ausência de uma política industrial mais abrangente, as estratégias empresariais focaram na racionalização de custo como alternativa para elevar seus níveis de competitividade. Acresce ainda que a política de juros elevados e a escassez de financiamentos de longo prazo foram dificuldades adicionais para ampliação das inversões na atividade produtiva.

Considerando o caso da indústria brasileira e conforme Leite (1999) o processo de introdução tanto de tecnologia física quanto de tecnologia organizacional e, sobretudo homens e informação, pode-se distinguir em três períodos: o primeiro, iniciado no final dos anos 70 e que se estendeu até meados da década de 80, marcado pela difusão dos círculos de qualidade; o segundo, que se estendeu de meados da década de 80 até o início da década de 90 e que se caracterizou pela rápida difusão de equipamentos e a adoção de várias técnicas japonesas de organização do trabalho como o just-in-time, CEP, kanban, trabalho em células; e o período iniciado no começo dos anos 90, quando efetivamente as empresas passaram a investir mais intensamente nas técnicas japonesas de gestão e organização, com ênfase na flexibilização do trabalho e no maior envolvimento do trabalhador com a qualidade e a produtividade.

Segundo Barros et al. (2008), as transformações sofridas pelo mercado de trabalho durante a década de 90 resultaram de um cenário macroeconômico conturbado, de mudanças na condução das políticas públicas e de avanços tecnológicos, que culminou na redução do emprego formal e expansão das relações informais de trabalho.

O Plano Real, ao reduzir a inflação, alterou a dinâmica de ajuste rápido de salários reais e contabilidade das empresas. De acordo com Ramos e Brito (2003), com a âncora cambial e um mercado aberto ao exterior, a importação maciça de bens substitui o mecanismo de aumento de preços existentes em épocas anteriores. O setor produtivo nacional teve de mudar radicalmente sua forma de ação e isso se traduziu na importação maciça de bens de capital para reduzir-se os custos - aumentar a eficiência e adaptar-se - ou mesmo no fechamento das unidades produtivas que não conseguiam sobreviver na nova situação. 
Se na década de 1990 os indicadores do mercado de trabalho apresentam uma piora considerável, uma leve recuperação pode ser sentida no período a partir de 2004 sem, no entanto, ter o alcance necessário para a solução dos diversos problemas que se configuraram desde o início dos anos 1990 (FAUSTINO et al. 2010).

Nesta perspectiva para Ramos e Brito (2003), isso explica o gradual, mas firme incremento da taxa de desemprego médio anual durante os anos de 1995 até 1998. A indústria de transformação, que foi, sem dúvida, o segmento mais afetado pelo processo de abertura e exposição da economia à concorrência internacional experimentou uma perda de importância relativa, com sua participação do nível de ocupação caindo da faixa de 19,5\% em 1991 para o patamar de $15 \%$ no final de 1999, mantendo-se estável daí em diante.

Ambrózio (2009) destaca que, entre 1996 e 1999, houve no setor de serviços uma destruição líquida de cerca de 300 mil postos de trabalho (50 mil por ano), enquanto no período 2000-2005, houve uma recuperação de modo expressivo, quando foram criados, liquidamente, cerca de 1,5 milhões de novos postos na indústria de transformação (300 mil por ano). Como resultado, esse setor perdeu participação no emprego total, entre 1996 e 1999 (caindo de 20,8\% para 18,4\%) e, depois, manteve estável a sua participação, apesar do crescimento observado, em 18,5\% em 2005.

Pelo que se pode observar, na década de 1990, o mercado de trabalho brasileiro passou por significativas transformações, resultado da dinâmica das políticas macroeconômicas implementadas no período.

\section{Política de Promoção à Industrialização}

Do ponto de vista conceitual e segundo Kupfer e Hasenclever (2002) a política industrial deve ser entendida como o conjunto de incentivos e regulações associadas a ações públicas, que podem afetar a alocação inter e intra-industrial de recursos, influenciando a estrutura produtiva e patrimonial, a conduta e o desempenho dos agentes econômicos em determinado espaço nacional.

$\mathrm{Na}$ análise do processo de industrialização do Ceará, adota-se a periodização proposta por Amora (2005), que identifica três períodos de implantação da indústria do estado e que correspondem a momentos distintos da divisão internacional e nacional do trabalho: o primeiro inicia-se no final do século XIX e estende-se até os anos de 1950; o segundo compreende os anos de 1960 até meados da década de 1980, quando começa um terceiro 
período, ainda em curso, o que tem maior relevância, devido às ações modernizadoras voltadas para dinamizar o setor industrial. O seu papel, na história cearense, é tão destacado que esse período passou a chamar-se "Era das Mudanças" ou "Governo das Mudanças".

De acordo com Pereira Júnior (2005), desde a emergência do 'Governo das Mudanças', a industrialização é abertamente um dos maiores interesses dos programas econômicos adotados pelo Ceará. A ação do Estado objetiva desenvolver mecanismos para a atração e consolidação de investimentos industriais, sendo os incentivos fiscais, o apoio financeiro e a implantação de uma infraestrutura básica de funcionamento suas principais preocupações.

Em 1991 Ciro Gomes assume o governo, mantendo o interesse em continuar investindo na industrialização do Estado. Na continuidade do projeto político, está o governo de Tasso Jereissati que conforme Amaral Filho comenta (1997) os fatores que contribuíram para a ascensão de Tasso Jereissati ao poder: a queda do regime militar, onde constituía a base de sustentação das lideranças políticas tradicionais; alinhamento das novas classes dirigentes à Nova República; a própria concepção desses empresários-políticos em relação à questão sócio-política e suas conseqüências. As pretensões do governo Tasso Jereissati seriam: acelerar a taxa de crescimento econômico, assegurar a criação de empregos produtivos e melhorar as condições de saúde e de educação da população (CEARÁ, 1987).

De acordo com Almeida (2001) o primeiro governo Tasso Jereissati pretendia criar uma indústria forte o bastante para gerar externalidades positivas, melhorando a situação da economia cearense tanto no contexto regional como nacional. Por trás dessa significativa injeção de investimentos externos, encontrava-se um definido programa de atração industrial no qual o principal instrumento de financiamento ainda era o Fundo de Desenvolvimento Industrial do Ceará (FDI). É preciso enfatizar que os investimentos ainda usufruem dos incentivos oferecidos pelos órgãos nacionais e regionais como o FINOR (Fundo de Investimento do Nordeste), o FNE (Fundo Constitucional de Financiamento do Nordeste) e o BNDS (Banco Nacional de Desenvolvimento Econômico e Social), todos consumidos de maneira cumulativa aos já concedidos pelo FDI/PROVIN.

Esta política industrial propunha-se a apoiar a expansão e fortalecimento das micro e pequenas empresas; consolidar o III Pólo Industrial do Nordeste por meio de projetos industriais de grande porte; incentivar a interiorização da indústria e, portanto, do desenvolvimento; elevar o nível de qualificação da mão-de-obra e o nível tecnológico do setor: incentivar a implantação de mini-distritos e galpões industriais nas áreas que apresentam potencialidades específicas (CEARÁ, 1987). 
Para dar suporte ao processo de industrialização, o Plano de Mudanças de 1987 a 1991 criou os seguintes programas prioritários: Programa de Investimentos Federais, Programa de Apoio às Micro e Pequenas Empresas, Programa de Agroindústria, Programa de Promoção Industrial, Programa de Assistência e Extensão Tecnológicas, Programa de Capacitação e Aperfeiçoamento de Recursos Humanos, Programa de Fortalecimento das Indústrias Tradicionais e Programa de Apoio Infra-estrutural ao Desenvolvimento Industrial (CEARÁ, 1987).

Posteriormente, o Plano Ceará Melhor (1992-1995) lançou programas que foram consolidados na política industrial, sendo os principais pontos: consolidar os complexos industriais e atrair novos investimentos; estimular a formação de Pólos Industriais; expansão e fortalecimento das micro e pequenas empresas, capazes de absorver um maior contingente de mão-de-obra; qualificar a mão-de-obra; modernizar, diversificar, verticalizar e dinamizar o parque industrial do Estado, especialmente nos setores mais tradicionais; implantar a infraestrutura para o desenvolvimento da indústria (CEARÁ, 1992).

Na continuidade desta proposta governamental, no ano de 1995, assume pela segunda vez o governo Tasso Jereissati, lançando o "Plano de Desenvolvimento Sustentável” (PDS), apresentando semelhanças com os planos preexistentes, entretanto, buscando consolidar os programas anteriores em seu plano atual. (Plano de Mudanças de 1987 a 1991). Entre os objetivos gerais deste plano estavam as seguintes prioridades: proteção ao meio ambiente, reordenamento do espaço cearense, capacitação da população, crescimento da economia, geração de empregos e redução de desigualdades, desenvolvimento da cultura e melhorias da gestão pública.

Ademais, entre os anos 1999 e 2002 Tasso Jereissati assume novamente o poder estadual e seu governo continua sendo orientado pelo "Plano de Desenvolvimento Sustentável" (PDS) onde objetiva promover o crescimento e desenvolvimento econômico do Ceará através da viabilização das seguintes estratégicas, segundo Ceará (2000): estimular a consolidação da indústria de base; diversificar e descentralizar a estrutura produtiva com investimentos industriais; potencializar a indústria do turismo; desenvolver uma indústria cultural local; e construir e modernizar a infraestrutura física.

No tocante à interiorização da Indústria no Ceará, em 1986 o governador Tasso Jereissati inicia o mandato com o objetivo principal de inserir no Estado no modelo de mundialização da produção, visando aumentar a produtividade e rentabilidade do capital. Neste sentido, implantam-se três eixos principais para as ações: a interiorização da indústria, pela implantação de novas indústrias e modernização do atual parque industrial; 
modernização da agricultura, pelo agronegócio e turismo, com a instalação de equipamentos necessários para a inserção das áreas litorâneas na rota nacional e conseqüente expansão do comércio e dos serviços. Mesmo com os três eixos prioritários, a industrialização tem arrecadado maiores investimentos, pelo caráter de atração e concentração da atividade industrial e pelo discurso de produção de emprego e geração de renda.

\section{A questão do Fundo de Desenvolvimento Industrial do Ceará}

Consciente das limitações impostas às operações industriais no Ceará, as quais poderiam onerar a produção, o governo estadual criou em 1979 um programa de incentivos fiscais e financeiros operacionalizados predominantemente pelo Fundo de Desenvolvimento Industrial do Ceará - FDI (CEARÁ, 2011).

Historicamente, a primeira regulamentação do FDI perdurou sem grandes modificações até o ano de 2000, quando foi dado início uma nova proposta de política industrial do Ceará. Desta forma, a Secretaria de Desenvolvimento Econômico e o Centro de Estratégias de Desenvolvimento do Ceará (CED) reviram os critérios de concessão de benefícios, dando um maior enfoque para a formação e consolidação das cadeias produtivas prioritárias do Estado (AMORIM, CARVALHO e AMARAL, 2002).

Segundo informa o Conselho Estadual de Desenvolvimento Econômico (CEARÁ, 2011), a segunda geração da Política Industrial está descrita nos Decretos 26.840 e 26.841/2002 e teve como objetivo básico não apenas atrair novos empreendimentos do setor secundário, mas, sobretudo fixá-los através da inserção e vinculação desses aos diversos conjuntos industriais em operação no Estado.

Nessa versão da política industrial houve uma atenção especial às micro e pequenas empresas, pois a nova política foi fundamentada em dois grandes pilares: 1) Política Seletiva de Atração de Investimentos e 2) Política de Apoio e Indução do Desenvolvimento Industrial. A Política Seletiva de Atração de Investimentos tinha como instrumento financeiro o FDI que deveria apoiar a atração de empreendimentos considerados essenciais para a formação e adensamento de cadeias produtivas estratégicas para o desenvolvimento do Estado, ou seja, voltada aos grandes empreendimentos industriais (IPECE, 2010).

A política industrial descrita no documento "Política de Desenvolvimento Econômico do Ceará", lançada oficialmente em Junho de 2003, pela Secretaria de Desenvolvimento Econômico do Ceará - SDE (CEARÁ, 2011) destaca que terão prioridades os seguintes 
aspectos: interiorização do setor industrial; promoção e competitividade das indústrias; fomento à implantação de micro, pequenas e médias empresas; consolidação do complexo portuário do Pecém; promoção da ciência e tecnologia como elemento estratégico de desenvolvimento industrial; promoção da visão industrial inovadora e empreendedora; e a política de apoio e indução ao desenvolvimento industrial.

\section{Metodologia}

Esta seção objetiva apresentar a metodologia compreendendo aspectos associados à tipologia da pesquisa e aos procedimentos de coleta de dados. A base de dados foi extraída da Relação Anual de Informações Sociais (RAIS) do Ministério do Trabalho e Emprego.

\section{Tipologia da Pesquisa}

$\mathrm{Na}$ literatura sobre metodologia científica, os autores se utilizam de diferentes abordagens sobre as tipologias de pesquisa. Neste estudo será utilizada a classificação feita por Raupp e Beuren (2003). Segundo esses autores, as pesquisas podem ser classificadas em três categorias: quanto aos objetivos: exploratória, descritiva e explicativa; quanto aos procedimentos: bibliográfica, documental, estudo de caso, levantamento, experimental, e participante; e quanto à natureza do problema: qualitativa ou quantitativa.

Quanto aos objetivos, o trabalho foi enquadrado como pesquisa de natureza descritiva. A pesquisa de natureza descritiva, de acordo com Raupp e Beuren (2003), tem como objetivo observar os fatos, registrá-los, analisá-los, classificá-los e interpretá-los. É sob esse enfoque que se pretende conduzir o estudo do comportamento do primeiro emprego na indústria de transformação do Estado do Ceará.

Com relação aos procedimentos adotados trata-se de uma pesquisa bibliográfica. A pesquisa bibliográfica, de acordo com Vergara (2004, p.48) “é o estudo sistematizado desenvolvido com base em material publicado em livros, revistas, redes eletrônicas, isto é, material acessível ao público em geral.”

A pesquisa bibliográfica foi realizada em artigos, dissertações de mestrado, publicações de entidades relacionadas ao foco de estudo, como o Instituto Brasileiro de 
Geografia e Estatística (IBGE), Instituto de Pesquisas Estratégicas do Estado do Ceará (IPECE)

A abordagem quantitativa deverá ser utilizada, pois, conforme Richardson et al. (1999), os métodos quantitativos são frequientemente aplicados nos estudos descritivos que procuram descobrir e classificar a relação entre as variáveis, bem como nos que investigam a relação de causalidade entre fenômenos. O método quantitativo, como o próprio nome indica, caracteriza-se pelo emprego de técnicas estatísticas e representa, em princípio, a intenção de garantir a precisão dos resultados, evitar distorções de análise e interpretação, possibilitando, consequentemente, uma margem de segurança quanto às inferências.

\section{Coleta de Dados}

Esta pesquisa utilizou fontes secundárias. Nas fontes secundárias, conforme já supracitado, serão utilizados artigos, dissertações de mestrado, publicações de entidades relacionadas ao foco de estudo, como o Instituto Brasileiro de Geografia e Estatística (IBGE), Instituto de Pesquisas Estratégicas do Estado do Ceará (IPECE), e os dados do Relatório Anual de Informações Sociais (RAIS).

Faz-se necessário ressaltar algumas considerações sobre os dados da RAIS/MTE. Atentando para Resende e Wyllie (2005), essa base de dados apresenta algumas deficiências. A primeira diz respeito à abrangência dos dados da RAIS/MTE, que embora tenha cobertura nacional, abrange apenas os contratos formais de trabalho, o que pode distorcer as informações sobre a quantidade de emprego na região. Entretanto, segundo Resende e Wyllie (2005), na indústria há um baixo grau de informalidade, o que atenua essa distorção.

Observa-se outra deficiência na RAIS/MTE, segundo Resende e Wyllie (2005), sendo a falta de acompanhamento da declaração das empresas, o que pode resultar na distorção de informações. Em empresas multi-plantas, as empresas podem declarar todos os seus empregados na matriz, o que leva a uma superestimação dos dados na região da matriz e uma subestimação na região das outras indústrias. Enquanto em empresas multi-produtos, estas informações enquadram-se apenas na sua atividade principal, superestimando as informações sobre o produto principal e subestimando as informações sobre as outras atividades.

O estudo compreenderá a análise do período entre 1994 e 2009 do comportamento do primeiro emprego no Estado do Ceará na indústria de transformação. Essa variável será 
analisada através de tabelas e gráficos, evidenciando a evolução nas mesorregiões do Estado em relação ao primeiro emprego.

A pesquisa se desenvolveu sob dois enfoques o contexto espacial e setorial. No contexto espacial, o campo de abrangência do estudo será o Estado do Ceará em termos de mesorregiões, que de acordo com o IBGE compreende sete: Noroeste Cearense, Norte Cearense, Metropolitana de Fortaleza, Sertões Cearenses, Jaguaribe, Centro Sul Cearense e Sul Cearense.

No que se refere ao enfoque setorial, a indústria de transformação é investigada de acordo com a Classificação Nacional das Atividades Econômicas (CNAE), constituída de vinte e três atividades dos setores de produção das mesorregiões cearenses. Com base nos dados da RAIS, nessas dimensões de análise, são utilizadas as seguintes informações: tamanho, gênero, idade e escolaridade, considerando-se as dimensões de número de estabelecimentos e emprego formal. Atenta-se que essas informações possibilitam traçar o perfil do primeiro emprego nas atividades industriais e das mesorregiões pesquisadas.

\section{Análise dos Resultados}

O estudo compreendeu a análise do período entre 1994 e 2009 do comportamento do primeiro emprego no Estado do Ceará na indústria de transformação à luz de dois enfoques: o contexto espacial e setorial. No contexto espacial, o campo de abrangência do estudo será o Estado do Ceará em termos de mesorregiões, que de acordo com o IBGE compreende sete: Noroeste Cearense, Norte Cearense. Metropolitana de Fortaleza, Sertões Cearenses, Jaguaribe, Centro Sul Cearense e Sul Cearense, ilustradas na figura 1. 
FIGURA1: Mapa das Mesorregiões Geográficas do Estado do Ceará

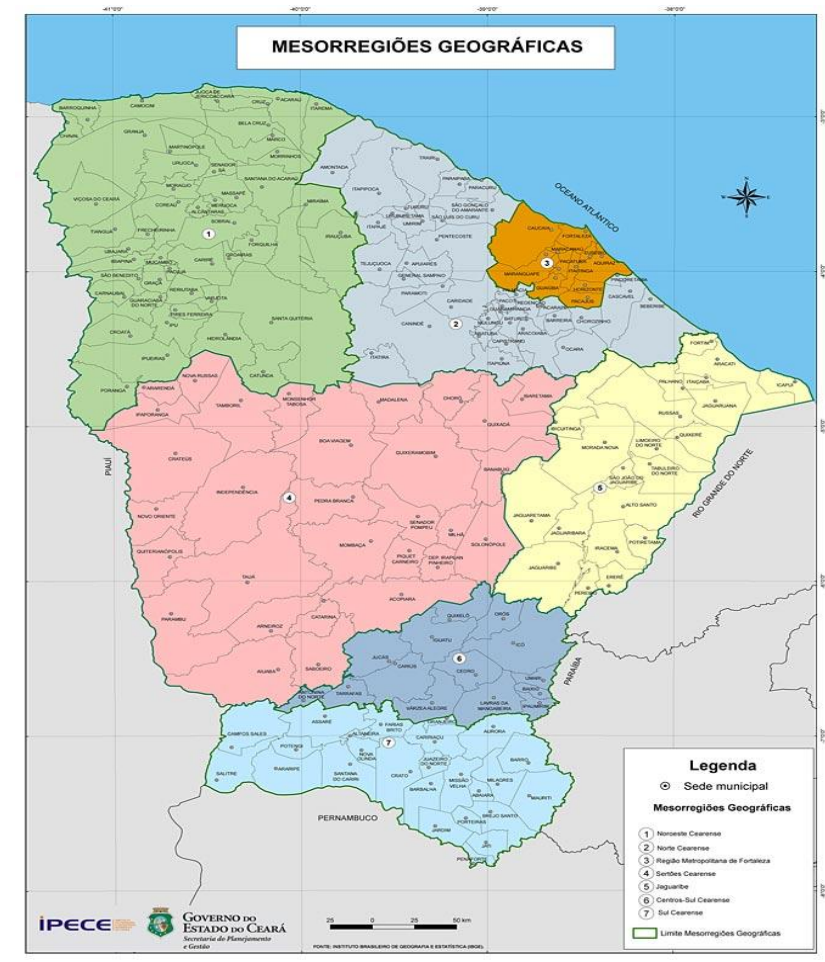

Fonte: IPECE, 2010

No que se refere ao enfoque setorial, a indústria de transformação é investigada de acordo com a Classificação Nacional das Atividades Econômicas (CNAE), constituída de vinte e três atividades.

A economia brasileira ingressou nos anos 90 num cenário de abertura da economia e reestruturação produtiva. No Estado do Ceará, esta nova fase da economia configura-se na preocupação diante da necessidade de reestruturação espacial e produtiva. De acordo com Coimbra e Rosa (1999) isso ocorreu em virtude do fortalecimento da divisão políticoadministrativa do Estado do Ceará em áreas de Desenvolvimento Regional (ADRs) cuja finalidade é o dimensionamento e divisão das ações a serem implantadas com o objetivo de reverter as disparidades existentes, promovendo o desenvolvimento em todos os espaços do Estado. 
Tabela 1: Estabelecimentos dos Setores de Transformação do Ceará por Mesorregiões 1994 e 2009

\begin{tabular}{lrrrrr}
\hline \multicolumn{1}{c}{ MESORREGIÃO } & 1994 & $\%$ & 2009 & $\%$ & Variação (\%) \\
\hline Noroeste Cearense & 124 & 3,78 & 1563 & 8,11 & 1160,48 \\
Norte Cearense & 83 & 2,53 & 1185 & 6,15 & 1327,71 \\
Metropolitana de Fortaleza & 2604 & 79,29 & 12040 & 62,5 & 362,37 \\
Sertões Cearenses & 72 & 2,19 & 936 & 4,86 & 1200,00 \\
Jaguaribe & 133 & 4,05 & 1200 & 6,23 & 802,25 \\
Centro-Sul Cearense & 23 & 0,70 & 574 & 2,98 & 2395,65 \\
Sul Cearense & 245 & 7,46 & 1766 & 9,17 & 620,82 \\
Total & 3284 & 100 & 19264 & 100 & 486,6 \\
\hline
\end{tabular}

Fonte: Autora, com dados da RAIS

Conforme dados da tabela 1, observa-se que em todas as mesorregiões houve um aumento destacando-se que a representatividade dos estabelecimentos da mesorregião Metropolitana de Fortaleza que em 1994 era de 79,29\%\%, em 2009 diminuiu para 62,5\%, o oposto do ocorrido nas demais mesorregiões.

Atenta-se para o fato de que empresas foram instaladas na última década no Estado do Ceará e contribuíram para a elevação do emprego e das ocupações. Nesta perspectiva merecem destaque a Grendene, instalada nas mesorregiões do Noroeste Cearense e do Sul Cearense (nos municípios de Sobral e Crato, respectivamente), a Singer na Mesorregião Sul Cearense (no município de Juazeiro do Norte), além da Vicunha, Marisol e a Indústria de Papel Laminado Rigesa, na Região Metropolitana de Fortaleza

Tabela 2 - Distribuição do Primeiro Emprego nos Setores de Transformação por Tamanho de Estabelecimento no Estado do Ceará -1994 e 2009

\begin{tabular}{|c|c|c|c|c|c|}
\hline \multirow{2}{*}{$\begin{array}{l}\text { TAMANHO DO } \\
\text { ESTABELECIMENTO }\end{array}$} & \multicolumn{2}{|c|}{1994} & \multicolumn{2}{|c|}{2009} & \multirow[b]{2}{*}{ VARIAÇÃO (\%) } \\
\hline & QUANT & $\%$ & QUANT & $\%$ & \\
\hline ATÉ 4 & 601 & 4,32 & 1582 & 5,01 & 136,44 \\
\hline DE 5 A 9 & 735 & 5,28 & 1678 & 5,32 & 128,30 \\
\hline DE 10 A 19 & 1075 & 7,73 & 2279 & 7,22 & 112,00 \\
\hline DE 20 A 49 & 1503 & 10,81 & 3485 & 11,04 & 131,87 \\
\hline DE 50 A 99 & 1001 & 7,20 & 2331 & 7,39 & 132,87 \\
\hline DE 100 A 249 & 1006 & 7,23 & 2959 & 9,38 & 194,14 \\
\hline DE 250 A 499 & 1462 & 10,51 & 2257 & 7,15 & 54,38 \\
\hline DE 500 A 999 & 2728 & 19,61 & 2097 & 6,64 & $-23,13$ \\
\hline
\end{tabular}


1000 OU MAIS

TOTAL
3798

$13909 \quad 100,00$

27,31

12891

40,85

239,42

FONTE: A autora, com dados da RAIS

O Serviço Brasileiro de Apoio às Micro e Pequenas Empresas (SEBRAE) utiliza o critério por número de empregados do IBGE para classificação do porte das empresas industriais sendo: micro com até 19 empregados, pequena de 20 a 99 empregados, média de 100 a 499 empregados, e grande a partir de 500 empregados.

A tabela 2 mostra que houve uma maior concentração de primeiro emprego nas empresas consideradas de grande porte. Através dos dados apresentados pode-se perceber o aumento do número do primeiro emprego nas micro, pequenas, médias e grandes empresas quando comparados os períodos de 1994 e 2009, permitindo também que a representatividade desses números sobre o total oscilasse em pequenas proporções.

\section{Primeiro Emprego por Mesorregiões Cearenses}

\section{Mesorregião Noroeste Cearense}

O setor de transformação a Mesorregião do Noroeste Cearense abriga empresas de grande porte como a Grendene em Sobral, além de outras nos setor têxtil e de bebidas (principalmente na região da Serra da Ibiapaba).

Conforme demonstra a figura 3, do período em análise, o ano de 1999 apresentou o menor contingente de trabalhadores no setor de transformação da mesorregião do Noroeste. Apesar das oscilações, os 7.381 empregos de 2009 caracterizam um aumento de $749 \%$ quando comparados com os ofertados em 1994. Destaca-se, aí, as vagas ofertadas na preparação de couro e fabricação de artefatos de couro e na fabricação de produtos alimentares e bebidas.

Figura 2 - Primeiro Emprego na Mesorregião do Noroeste Cearense 1994 a 2009

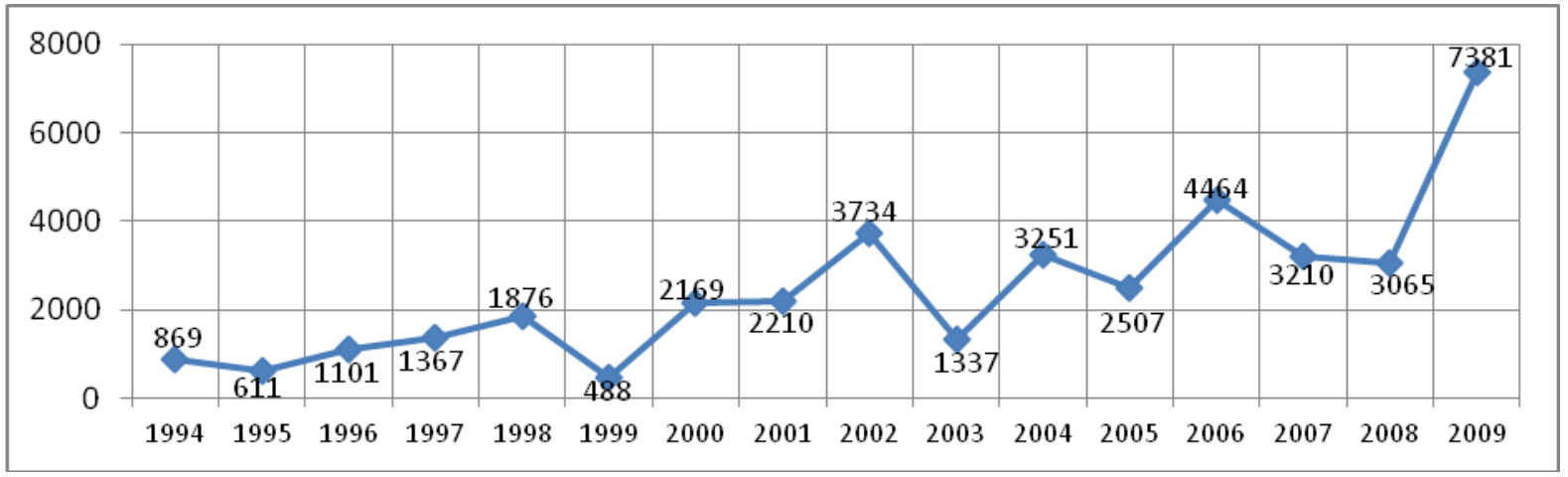


Fonte: Autora, com dados da RAIS

Em 1994 o setor empregava 2.967 trabalhadores (59,08\% de todos os empregos da mesorregião), dos quais 16,65\% referiam-se ao primeiro emprego. Em 2009 o mesmo setor empregava 24.334 de trabalhadores dos quais $27,18 \%$ referiam-se ao primeiro emprego.

Ao considerar o fator gênero no comportamento do primeiro na Mesorregião Noroeste Cearense percebeu-se que houve uma inversão da quantidade de vagas ocupadas por homens e mulheres quando comparados os períodos de 1994 e 2009. A lotação de mulheres no primeiro emprego na indústria de transformação era de 56,17\%. Em 2009, os trabalhadores no primeiro emprego do sexo masculino preenchiam o maior número de vagas, $51,32 \%$.

O setor de transformação da referida mesorregião tem lotado mais trabalhadores no primeiro emprego com idades de 18 a 24 anos. Quanto ao nível de escolaridade verificou-se uma redução no número de trabalhadores com até a $4^{\mathrm{a}}$ série, logo o índice de trabalhadores com o $2^{\circ}$ grau concluído que em 1994 era de 4,27\% aumentou para 46,58\% em 2009.

\section{Mesorregião Norte Cearense}

Com o objetivo de fortalecer e dar sustentabilidade ao crescimento do parque industrial do Ceará, possibilitando a promoção de atividades industriais integradas, foi implantado na Mesorregião Norte o Complexo Industrial e Portuário do Pacém que teve suas operações comerciais iniciadas em 2001.

Figura 3 - Primeiro Emprego na Mesorregião Norte Cearense 1994 a 2009

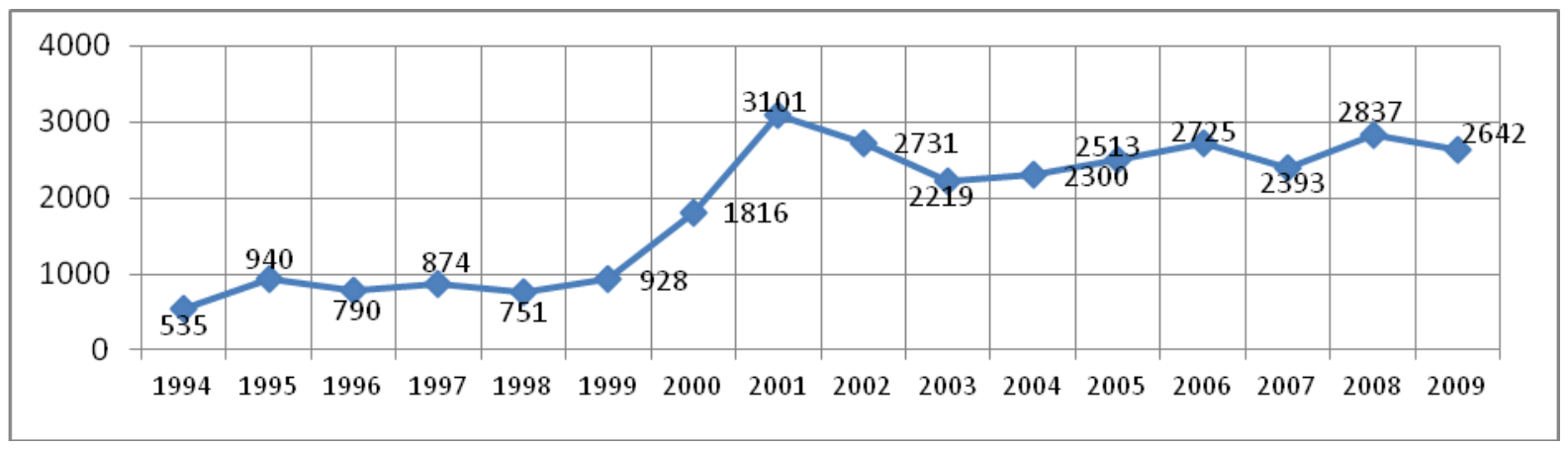

Fonte: Autora, com dados da RAIS

Conforme mostra a figura 3 a mesorregião Norte Cearense apresentou em 2001 o melhor desempenho no que concerne a número de trabalhadores lotados nos setores produtivos. Também nesta mesorregião a preparação de couro e fabricação de artefatos de 
couro se destaca como o setor que mais evoluiu em termos de aquisição de mão-de-obra. As empresas Cascavel Couros Ltda. (instalada no município de Cascavel no ano de 1999) e Dass Nordeste Calçados e Artigos Esportivos (instalada no município de Itapipoca também no ano de 1999), ambas com utilização de benefícios do FDI muito contribuíram para a elevação aumento do primeiro emprego na mesorregião Norte Cearense.

Verificou-se nesta mesorregião uma inversão da quantidade de vagas ocupadas por homens e mulheres no setor de transformação quando comparados os períodos analisados. A lotação de mulheres no primeiro emprego que em 1994 correspondia a 57,01\%, em 1994 representava apenas $36,15 \%$ do total. No que se refere à idade, os trabalhadores na faixa etária de 18 a 24 anos são em maior número. Também houve uma diminuição representativa no número de trabalhadores com até o $4^{\circ}$ ano concluído. $\mathrm{O}$ índice de trabalhadores com o $2^{\circ}$ grau completo aumentou de 14,39\% em 1994 para 54,24\% em 2009.

\section{Mesorregião Metropolitana de Fortaleza}

A figura 4 aponta uma estabilidade do primeiro emprego na mesorregião Metropolitana de Fortaleza nos períodos de 1994 a 2004. Entretanto, somente a partir de 2005 o número de trabalhadores no primeiro emprego nos setores produtivos dessa mesorregião evidenciou aumento, apresentando crescimento de mais de $40 \%$ quando comparados os números de 2009 com os de 1994.

Figura 4 - Primeiro Emprego na Mesorregião Metropolitana de Fortaleza 1994 a 2009

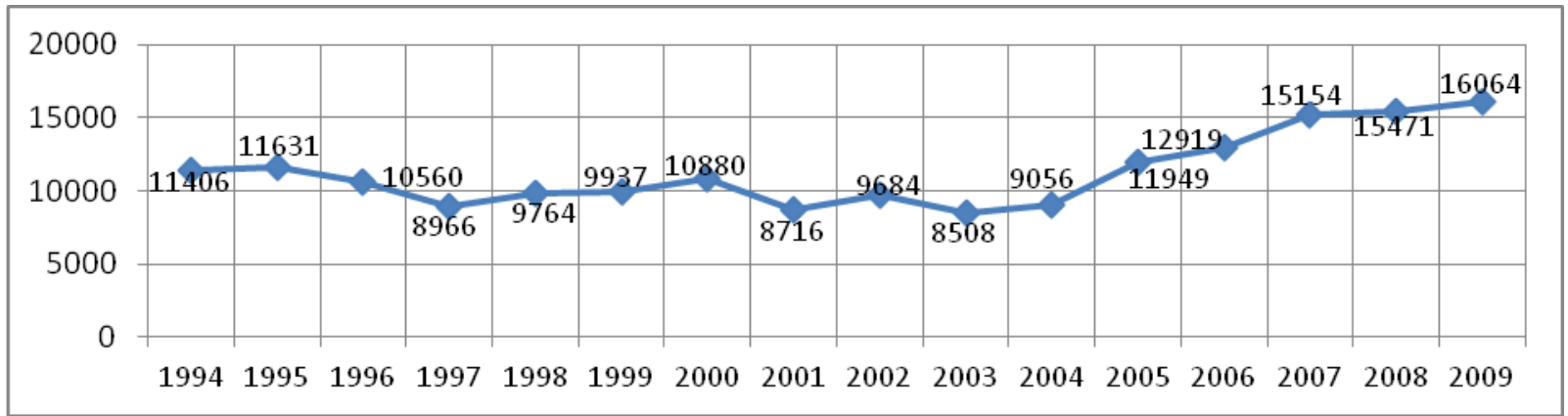

Fonte: Autora, com dados da RAIS

No período de 1994 a 2009 houve um aumento no total de empregos nas indústrias de transformação da Mesorregião Metropolitana de Fortaleza, portanto a representatividade do primeiro emprego sobre o total diminuiu em quase todos os setores. Em 1994 dos 87.240 
trabalhadores no setor de transformação da mesorregião $13,07 \%$ referiam-se a primeiro emprego. Em 2009 esse mesmo índice era de 10,49\%.

No tocante ao gênero do primeiro emprego nesta mesorregião, os dois períodos analisados apresentam uma predominância do trabalhador do sexo masculino. Essa predominância se apresentou mais acentuada em 2009 (54\%) que em 1994 (51,36\%). O primeiro emprego é também em maior número na faixa etária de 18 a 24 anos.

No que se refere à escolaridade, em 1994 os trabalhadores do primeiro emprego com a $8^{a}$ série concluída e com o ensino médio concluído somavam $64,12 \%$ do total existente no setor de transformação da referida mesorregião. Em 2009 esse indicador era de 96,74\%.

\section{Mesorregião dos Sertões Cearenses}

Segundo a RAIS/MTE as indústrias de alimentos e de calçados destacam-se como as principais empregadoras no setor de transformação da mesorregião dos Sertões Cearenses.

Figura 5 - Primeiro Emprego na Mesorregião dos Sertões Cearenses 1994 a 2009

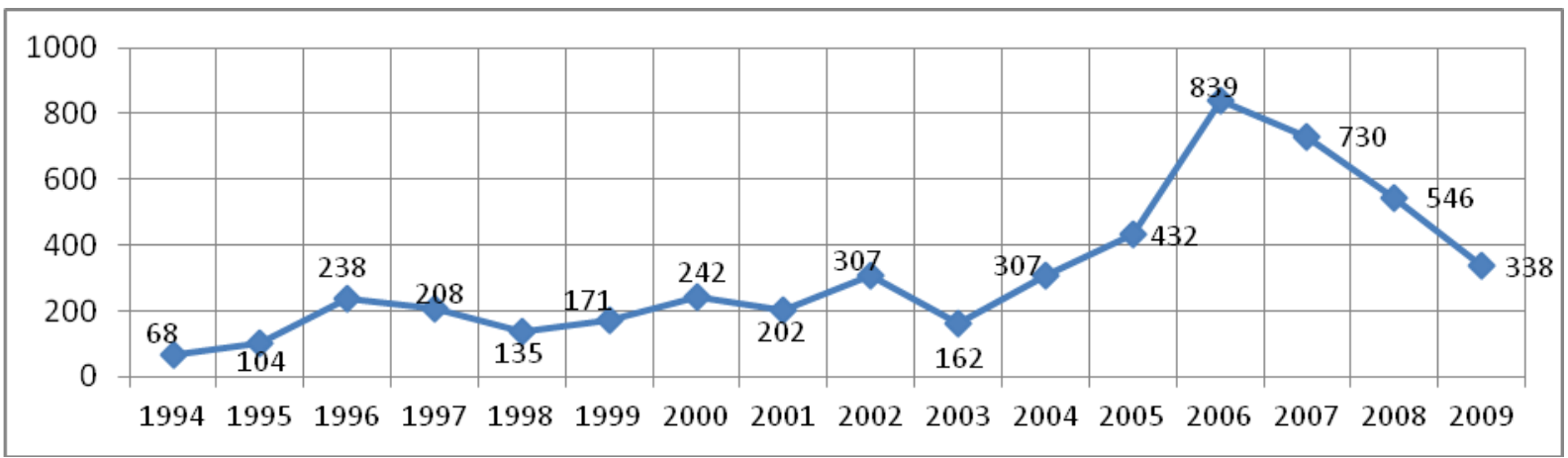

Fonte: Autora, com dados da RAIS

Observa-se através da figura 5, que a partir de 2005 a Mesorregião dos Sertões Cearenses apresentou um crescimento na absorção de trabalhadores do primeiro emprego nos setores produtivos alcançando seu ápice maior em 2006, porém ocorreu um declínio sucessivo anos de 2007, 2008 e 2009. Ainda assim, os 338 trabalhadores lotados no exercício de 2009 superam em mais de 397\% os 68 trabalhadores lotados em 1994. O acentuado crescimento no ano de 2006 aconteceu principalmente pela absorção de trabalhadores na fabricação de produtos alimentares e bebidas assim como na preparação de couro e fabricação de artefatos de couro. 
O setor de transformação cuja evolução do primeiro emprego tornou-se mais acentuada foi o de fabricação de produtos alimentares e bebidas. Em 1994, dos 161 empregos existentes neste setor, 13,04\% referiam-se a primeiro emprego. Em 2009 esse índice era de 19,53\%.

Referindo-se ao gênero ficou constatada a predominância de trabalhadores do sexo masculino nos períodos de 1994 e 2009 (82,35\% e 71,89\% respectivamente). Em relação à idade, merece destacar o fato dos trabalhadores no primeiro emprego na faixa etária de 30 a 39 anos serem mais representativos que aqueles da faixa etária de 25 a 29 anos. Ainda assim, as indústrias de transformação dessa mesorregião têm ofertado mais vagas para primeiro emprego para pessoas da faixa etária de 18 a 24 anos. Quanto à escolaridade constatou-se que em 1994, os trabalhadores que haviam cursado até a $4^{\mathrm{a}}$ série representavam $69,12 \% \%$. Em 2009 apenas 9,17\% desses trabalhadores possuíam essa escolaridade.

\section{Mesorregião do Jaguaribe}

No setor de transformação da mesorregião do Jaguaribe, as indústrias de calçados e de alimentos e bebidas se destacam como as principais empregadoras.

Figura 6- Primeiro Emprego na Mesorregião do Jaguaribe 1994 a 2009

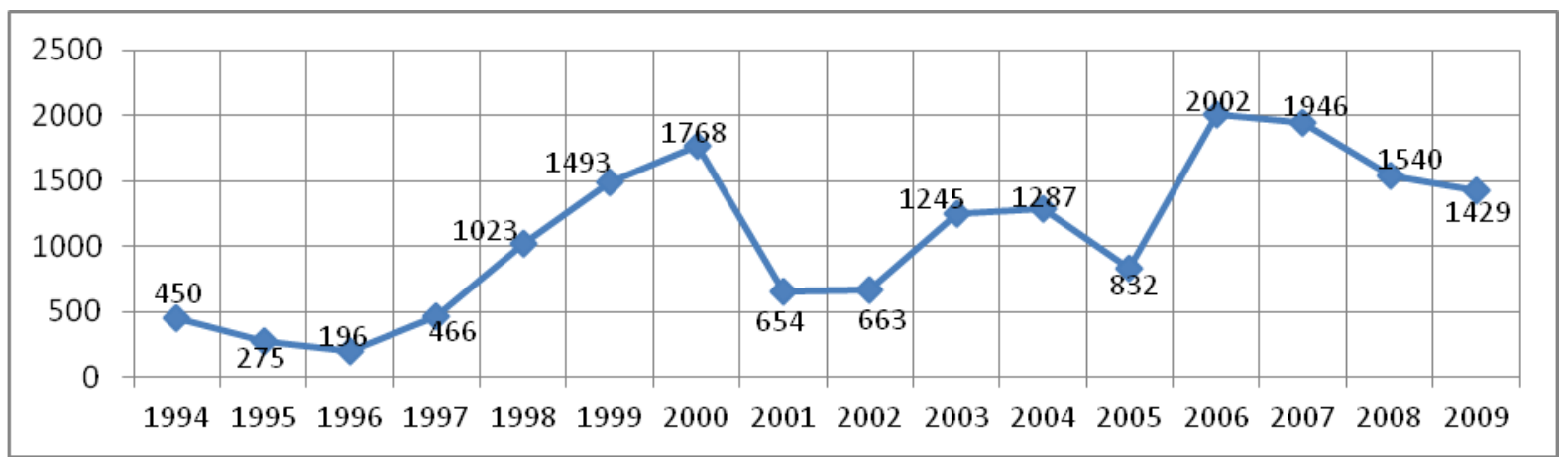

Fonte: Autora, com dados da RAIS

A figura 6 ilustra uma evolução do primeiro emprego no período de 1994 a 2000 e, logo entre 2001 e 2005 uma desaceleração desses números. O aumento do primeiro emprego no setor de fabricação de produtos alimentares e bebidas e no setor de preparação de couros e fabricação de artefatos de couros foi o principal responsável pelo aumento desse indicador a partir de 2006.

De acordo com a RAIS, em 2009 o índice do primeiro emprego em relação ao emprego total no setor de transformação na mesorregião do Jaguaribe $(15,10 \%)$ diminuiu 
quando comparado com o de 1994 (26,19\%). O setor de fabricação de produtos minerais não metálicos aparecem como um dos principais responsáveis pela redução desse índice, uma vez que em 1994 os trabalhadores no primeiro emprego nesse setor correspondiam a 46,40\% do total de empregos e em 2009 esse indicador era de apenas 14,79\%.

Em relação ao sexo, em 1994 o primeiro emprego na mesorregião do Jaguaribe era predominantemente ocupado por trabalhadores do sexo masculino (89,78\% do total); em 2009 as mulheres já representavam 34,43\%. A exemplo das demais mesorregiões, o setor lotou mais trabalhadores no primeiro emprego com idades entre 18 a 24 anos, evoluindo a representatividade, inclusive, de 39,19\% em 1994 para 67,60\% em 2009. Também na mesorregião do Jaguaribe os trabalhadores no primeiro emprego com até a $4^{\text {a }}$ série diminuíram quando comparado o ano de 2009 com o ano de 1994 (76,22\% e 4,83\% respectivamente).

\section{Mesorregião Centro-Sul Cearense}

O setor de transformação da mesorregião do Centro-Sul Cearense apresenta uma grande concentração de indústrias moveleiras, especialmente as de móveis tubulares na cidade de Iguatu.

Figura 7 - Primeiro Emprego na Mesorregião do Centro-Sul Cearense 1994 a 2009

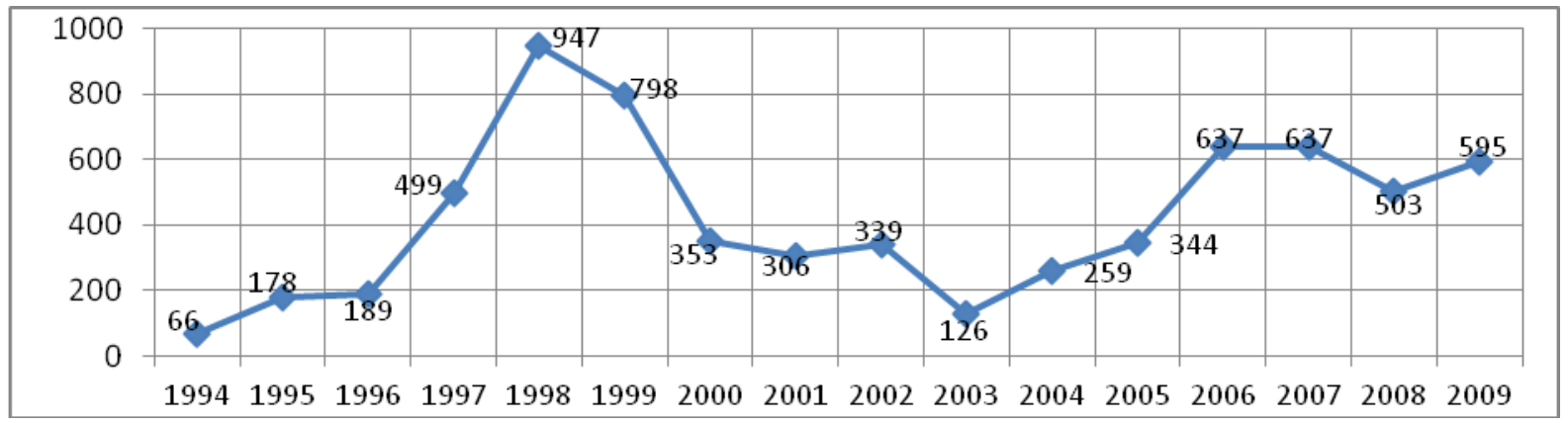

Fonte: Autora, com dados da RAIS

O número de trabalhadores na Mesorregião Centro-Sul Cearense alcançou maior representatividade nos anos de 1998 e 1999. O setor de preparação de couro e fabricação de artefatos de couro foi o principal impulsionador desse crescimento, pois em 1996 eram poucos os trabalhadores lotados nesse setor. Dada a queda no período de 2000 a 2005, em 2006 o setor de fabricação de móveis impulsionou a retomada do crescimento contribuindo 2009 atingir os 595 primeiros empregos. 
A média de trabalhadores do sexo masculino no primeiro emprego na mesorregião do Centro-Sul Cearense aumentou em 2009 (78,49\%) quando comparada com a média de 1994 $(69,70 \%)$. O aumento de empresas que demandam por mais mão-de-obra masculina, como o setor de fabricação de móveis e indústrias diversas, se apresenta como um dos fatores que contribuiu para o avanço desse indicador.

A participação do primeiro emprego na referida mesorregião mostra que os trabalhadores com idade entre 18 e 24 anos são maioria nos anos de 1994 e 2009, apresentando, inclusive, um aumento nessa representatividade (de 48,48\% para 63,53\%). Quanto ao grau de escolaridade observou-se um aumento do número de trabalhadores com até $2^{\mathrm{o}}$ grau concluído que em detrimento da diminuição daqueles haviam cursado até a $4^{\mathrm{a}}$ série evoluiu de 12,12\% em 1994 para 44,03\% em 2009.

\section{Mesorregião Sul Cearense}

$\mathrm{Na}$ mesorregião Sul Cearense calcula-se que o setor calçadista gera mais de 6.500 empregos formais e concentra 48\% das fábricas do Ceará (dados da RAIS 2008). Outras atividades de importância local são a indústria têxtil e a de borrachas.

Figura 8 - Primeiro Emprego na Mesorregião Sul Cearense 1994 a 2009

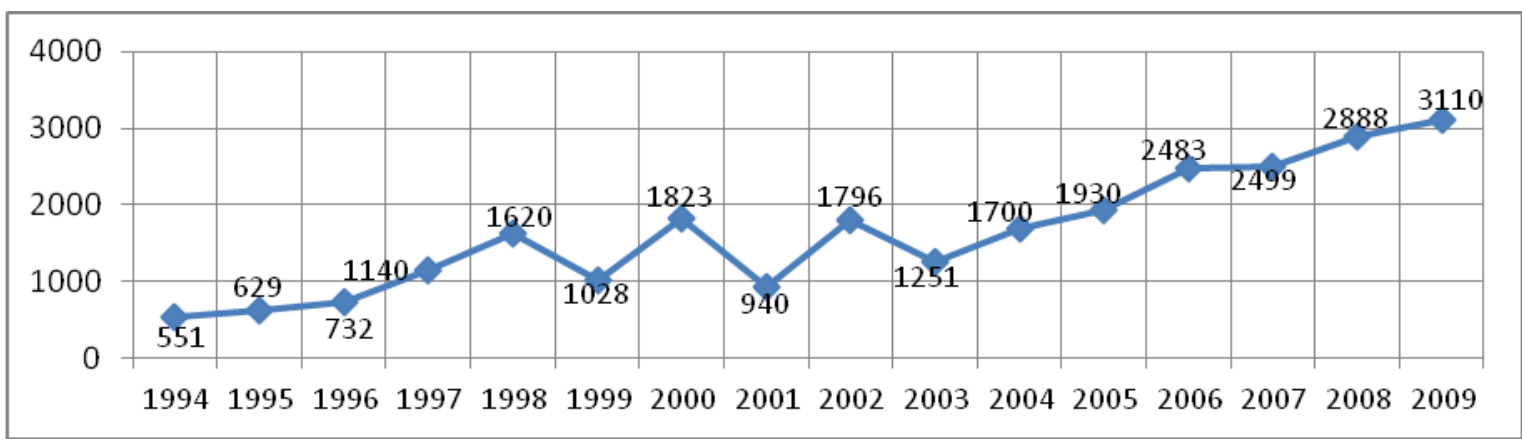

Fonte: Autora, com dados da RAIS

De acordo com a figura 8 pode-se perceber uma linha de tendência instável no período de 1994 a 2004 e uma ascendência a partir de 2005.A diminuição dos índices nos anos de 1999 e 2001 foi evidenciada principalmente pela redução do número de trabalhadores no setor de preparação de couros e fabricação de artefatos de couro.

A mesorregião Sul Cearense também aponta uma predominância de trabalhadores do sexo masculino no primeiro emprego, embora seja evidenciado um aumento no número de 
mulheres empregadas nos setores de transformação (21,65\% em 1994 e 36,75\% em 2009). A exemplo das demais mesorregiões, mais vagas são ofertadas para trabalhadores na faixa etária de 18 a 24 anos, inclusive com uma elevação nesse índice de 43,92\% em 1994 para 63,79\% em 2009. A mesorregião Sul Cearense se destaca como a que em 2009 apresentou a maior concentração de trabalhadores no primeiro emprego com o $2^{\circ}$ grau concluído $(56,94 \%)$.

\section{Considerações finais}

O presente trabalho analisou o comportamento do primeiro emprego na indústria de transformação do Ceará no período 1994-2009. Para alcançar o objetivo pretendido, considerou-se o contexto de política econômica nacional e as políticas de apoio à industrialização implementada pelo Estado.

Assim sendo, observou-se em todas as mesorregiões um aumento do número de estabelecimentos das atividades componentes da indústria de transformação, com reflexos no mercado de trabalho do primeiro emprego. Esse quadro corrobora com o pressuposto de que a interiorização promoveu o crescimento do primeiro emprego, em proporção maior à Região Metropolitana de Fortaleza, que apresentou menor crescimento relativo no período no primeiro emprego industrial. Quanto ao perfil do trabalhador do primeiro emprego na indústria de transformação cearense, observou-se que houve um aumento das exigências da qualificação, o que ocorreu em todas as mesorregiões e que continua havendo predominância do sexo masculino.

Verificou-se que algumas das empresas industriais, beneficiadas com os incentivos fiscais do FDI, foram instaladas nesta última década no Estado do Ceará, contribuindo assim para a elevação do emprego na indústria de transformação cearense, especialmente do primeiro emprego.

Sugere-se, no entanto, um maior aprofundamento dessa temática considerando uma pesquisa de campo nas empresas que se instalaram no Estado nesse período e que foram beneficiadas com as políticas de apoio à interiorização, para se analisar o real impacto dessas empresas no mercado de trabalho, em especial no primeiro emprego. 


\section{Referências}

ALMEIDA, Cleycianne de Souza. O impacto das políticas industriais na economia cearense. Monografia (Bacharelado em Economia). FEAAC/UFC, 2001,62p.

AMARAL FILHO, J. do. Ajuste no Estado e Crescimento Recente no Ceará: O papel dos 'Jovens Empresários'. Revista Economica \& Empresa, Universidade Mackenzie. São Paulo, vol. 4. n. 1, p.63-80, jan-mar 1997,

AMBRÓZIO ,A. M.H. Desaceleração do emprego não deve repetir anos 90. Visão do Desenvolvimento. BNDES. Nº 62, 2009.

AMORA, Z. B. Indústria e espaço no Ceará. In: SILVA, J.B. da S. (org.) et al. Ceará: um novo olhar geográfico. Fortaleza: Edições Demócrito Rocha, 2005.

AMORIM, M. A.,CARVALHO, E.B.S., AMARAL FILHO, J. do. Nova Política Industrial do Ceará, 2002.

BARROS, R. C. B. et al.. Diferenciação Regional da Geração de Empregos Formais no Brasil no Quadriênio 2003/2006. Revista Econômica do Nordeste Fortaleza, v. 39, nº 2, abrjun,2008.

BNB, 2010. Banco do Nordeste do Brasil. Páginas eletrônicas Disponível :

http://www.bnb.gov.br - Acesso em 15/08/2010.

CALMFORS, L. Active labour market policy and unemployment - a framework for the analisys of crucial design fatures. OECD, Economic Studies, 22 Spring 1994.

BRASIL. Lei 8.900, de 30 de junho de 1994. Dispõe sobre o Benefício Seguro-Desemprego. Disponível em: < www.guiatrabalhista.com.br/legislação > Acesso em: 01/03/2011

Lei $\mathbf{n}^{\circ}$ 10.478, de 23 de outubro de 2003. Criou o Programa Nacional de Estímulo ao Primeiro Emprego Disponível em: < www.guiatrabalhista.com.br/temáticas $>$. Acesso em: 18 jun. 2010. 
Lei $\mathbf{n}^{\circ} \mathbf{1 0 . 9 4 0}$ de 27 de agosto de 2004. Altera e acrescenta dispositivos à Lei 10.478/03 que cria o Programa Nacional de Estímulo ao Primeiro Emprego - < www.guiatrabalhista.com.br/legislação> . Acesso em: 18 jun. 2010.

Lei ${ }^{\circ}$ 8.019/90 de 11 de Abril de 1990. Altera a Legislação do Fundo de Amparo ao Trabalhador. Disponível em: <www.planalto.gov.br> Acesso em: 07 jun 2011.

Lei $\mathbf{n}^{\circ}$ 7.998 de 11 de janeiro de 1990. Regula o Programa de Seguro- Desemprego, o Abono Salarial, institui o Fundo de Amparo ao Trabalhador (FAT) e dá outras providências. Disponível em: < $\underline{w w w . l e i d i r e t o . c o m . b r}>$. Acesso em: 19 jun. 2010.

Ministério do Trabalho e Emprego. Cadastro geral de empregados e desempregados: 2000 a 2005. Brasília, DF, 2005.

.Constituição da República Federativa do Brasil. Brasília, 1988.

Secretaria Geral da Presidência da República. Guia de Políticas Públicas de Juventude, 2006.

Secretaria Geral da Presidência da República. Guia de Políticas Públicas de Juventude, 2009.

Secretaria Geral da Presidência da República. Diretrizes de Política Industrial, Tecnológica e de Comércio Exterior, 2003.

CEARÁ, Industrialização do Estado do Ceará - 20 anos, por Hélio Beltrão. Palestra Economia e Finanças,2001. Disponível em: http://www.sfiec.gov.br.Acesso em 12/06/2010. ,Plano de Mudanças, 1987-1991. Fortaleza, SEPLAN, 1987. .Disponível: http:// www.seplan.gov.br. Acesso em 14/05/2010.

,Plano Ceará Melhor, 1992-1995. Fortaleza, SEPLAN, 1992. Disponível:http:// www.seplan.gov.br. Acesso em 14/05/2010. 
,Plano Estadual de Desenvolvimento Sustentável, 1995-1998. Fortaleza, SEPLAN, 1995. Disponível; http:// www.seplan.gov.br Acesso em 14/05/2010.

,Plano Estadual de Desenvolvimento Sustentável, 1999-2002. Fortaleza, SEPLAN, 2000. Disponível: http://www.seplan.gov.br.Acesso em 14/05/2010.

..Secretaria do Trabalho e Desenvolvimento Social. Programa Primeiro Passo. Disponível em: www.stds.ce.gov.br. Acesso em 02/02/2010.

. Conselho Estadual do Desenvolvimento Econômico. Disponível em www.cede.ce.gov.br. Acesso em: 03/03/2011.

DEDECCA, C.Notas sobre a evolução do mercado de trabalho no Brasil. Revista de Economia Política,v.1, n.25, Jan-Março de 2005.

EHRENBERG, Ronald G., SMITH, Robert S. A moderna economia do trabalho. Ed. Makron Books. São Paulo, 2005.

FAUSTINO, Izabel Aparecida et Al. Impactos das variáveis macroeconômicas sobre o emprego e o primeiro emprego no Brasil: uma análise para o período 1999 - 2009.XIII ENCONTRO REGIONAL DE ECONOMIA, 13, Anais.... Porto Alegre: ANPEC Sul, 2010.

IBGE, Sistema de Recuperação Programada. Disponível em: http:// www.sidra.ibge.gov.br. Acesso em 20/10/2010.

IBGE, Pesquisa Industrial Mensal de Emprego e Salário, 2007. Disponível em: www.ibge.gov.br. Acesso em 22/05/2009.

IBGE, Pesquisa Industrial Mensal de Emprego e Salário, 2010. Disponível em: www.ibge.gov.br. Acesso em 09/08/2009.

IPECE, Anuário Estatístico do Ceará, Fortaleza, 2009. 
IPECE, Anuário Estatístico do Ceará, Fortaleza, 2010.

KUPFER, D., HASENCLEVER, L.(Orgs). Economia Industrial: Fundamentos Teóricos e Práticas no Brasil. São Paulo, 2002.

LEITE, Elenice M. Renovação tecnológica e qualificação do trabalho:efeitos e expectativas. In: CASTRO, Nadya A. de (org.). A máquina e o equilibrista: inovações na indústria automobilística brasileira. Rio de Janeiro, Paz e Terra, p. 159-177, 1999.

NAJBERG, Sheila. PEREIRA, R.O. Sinopse Econômica. N 133 . Rio de Janeiro. Março, 2004. Disponível em:www.bndes.gov.br/conhecimento.Acesso em 03/03/2010.

NAJBERG, Sheila. IKEDA, Marcelo. Modelo de Geração de Empregos: Metodologia e Resultados. Textos para discurssão n 72. Rio de Janeiro; BNDES, 1999.

PEREIRA Jr., E. A. Industrialização e Reestruturação do Espaço - O caso de Horizonte Pacajus -Ce. Dissertação de Mestrado. Fortaleza : UECE, 2005.

POCHMANN, Márcio. Desemprego e políticas públicas de emprego: Tendências internacionais e o Brasil. In OLIVEIRA, Marcos Antonio(org). Economia \& Trabalho: Textos básicos. Campinas, SP: UNICAMP.IE, 1998.

POSTHUMA, Anne Caroline.Transformações do emprego no Brasil na década de 90. In:POSTHUMA, Anne Caroline (Org.) Aberturas e ajuste do mercado de trabalho no Brasil: políticas para conciliar os desafios de emprego e competitividade.Brasilia: OIT e TEM; São Paulo: Ed.34, 1999.

RAMOS, L. BRITO, M. Mercado de Trabalho, Nota Técnica, Rio de Janeiro: IPEA, 2003.

RAUPP, Fabiano Maury; BEUREN, Ilse Maria. Metodologia da Pesquisa Aplicável às Ciências Sociais. Como elaborar trabalhos monográficos em contabilidade. Ilse Maria Beuren. São Paulo: Atlas, 2003. 
RESENDE, M.; WYLLIE, R. Aglomeração industrial no Brasil: Um estudo empírico.

Estudos Econômicos, São Paulo, v. 35, n. 3, p. 433-460, jul./set. 2005.

TOKARSKI, Marcelo. Fim melancólico. Disponível em: http://www.ipea.gov.br

Sobre os Autores:

1. Diana Figueiredo Barbosa. Mestre em Administração e Controladoria pela Universidade Federal do Ceará, Professora da Faculdade Vale do Jaguaribe, Professora da Faculdade Católica do Crato, Professora da Universidade Vale do Acaraú. E-mail: dianabarbosaconsultoria@ hotmail.com

2. Dra. Sandra Maria Santos. Professora da Universidade Federal do Ceará - FEAAC. E-mail: smsantosufc@gmail.com

3. Dr. Francisco de Assis Soares. Professor da Universidade Federal do Ceará- FEAAC. E-mail: $\underline{\text { soares@ufc.br }}$

4. Ana Marilia Barbosa Sampaio. Especialista em Gestão Tributária pela Faculdade de Ciências Aplicadas Dr. Leão Sampaio. Professora da Faculdade de Ciências Aplicadas Dr. Leão Sampaio. E-mail: anamarilia@ hotmail.com

\section{Como citar este artigo (Formato ISO):}

BARBOSA, D.F.; SANTOS, S.M.; S, P.P.; SOARES, F.A.; SAMPAIO, A.M.B. O comportamento do primeiro emprego na indústria de transformação do estado do Ceará. Id on Line Revista de Psicologia, Julho de 2012, vol.1, n.17, p. 65-94. ISSN 1981-1189. 